\title{
Comparative resistance and yield performance of summer mungbean mutants and varieties as affected by MYMV
}

\author{
Md. Mahmudul Hasan Arif Sardar ${ }^{1}$, Habibur Rahman ${ }^{1}$, Md. Shahidul Islam ${ }^{1}$, Mohammad Saiful Alam \\ Sarker $^{2}$ \& Kazi Khayrul Bashar ${ }^{2 *}$
}

${ }^{1}$ Patuakhali Science and Technology University, Dumki, Patuakhali 8602, Bangladesh

${ }^{2}$ Bangladesh Jute Research Institute, Manik Mia Avenue, Dhaka 1207, Bangladesh

\section{Article history}

Received: 19 June 2019

Accepted: 18 July 2019

Published: 01 October 2019

\section{Publisher}

Horizon e-Publishing Group

\section{*Correspondence}

Kazi Khayrul Bashar

$\bigotimes$ kazi.khayrulbashar@gmail.com

\begin{abstract}
An experiment was conducted in the research field of the Department of Plant Pathology, Patuakhali Science and Technology University during February to April 2013 to select Mungbean Yellow Mosaic Virus (MYMV) resistant mutant/variety under natural epiphytotic condition. The screening was made on the six mungbean genotypes including three advanced mutant lines, MBM-07, MBM-21, MBM-88 and three varieties Bina mung-5, Bina mung-6, Bina mung- 8 as check, to evaluate their reaction to MYMV at flowering and pod maturity stages. It was observed that at the flowering stage of MBM21, MBM-88, and Bina mung-6 were found resistant with percent disease incidence recorded from $0.5,1.0$, and 0.5 percent respectively. At the maturity stage, no genotype were found to be immune and the disease incidence varied from the lowest $0.5 \%$ in MBM-21 to highest $26 \%$ in MBM-7. The mutant MBM-21 and variety Bina mung-6 were found moderately resistant with disease incidence ranging from 1 to $10 \%$. Among the less MYMV infected mungbean mutants, MBM-21 gave the highest yield (1569 kg ha-1) and the lowest yield was in MBM-07 (1183kg ha $\left.{ }^{-1}\right)$. The mutants MBM-21 completed by the short duration of 61.67 days as compared to check Bina mung-6 (67.33 days). Out of six summer screened mungbean mutants and varieties, MBM-21 exhibited highest resistance in both flowering and pod maturity stage. Therefore, MBM-21 might be selected as a resistant variety against MYMV after further trail in different AgroEcological Zones (AEZ) of Bangladesh.
\end{abstract}

Keywords: mungbean mutant; Mungbean Yellow Mosaic Virus; resistance; yield.

Citation: Sardar MMHA, Rahman H, Islam MS, Sarker MSA, Kazi Bashar K. Comparative resistance and yield performance of summer mungbean mutants and varieties as affected by MYMV. Plant Science Today 2019; 6(4):433-438. https://doi.org/10.14719/pst.2019.6.4.596

Copyright: (C) Sardar et al (2019). This is an open-access article distributed under the terms of the Creative Commons Attribution License, which permits unrestricted use, distribution, and reproduction in any medium, provided the original author and source are credited (https://creativecommons.org/licenses/by/4.0/).

Indexing: Plant Science Today is covered by Scopus, Web of Science, BIOSIS Previews, ESCI, CAS, AGRIS, CABI, Google Scholar, etc. Full list at http://www.plantsciencetoday.online

\section{Introduction}

Mungbean is considered as the second most important pulse crop based on both area (54982 ha) and production $(34,400 \mathrm{~m}$ tons) among the pulse crops in Bangladesh (1). But in the nutrient content point of view, it ranks first as a pulse crop (2). The people of Bangladesh consume mungbean as a major source of pulse and uptake only $10 \mathrm{gm}$ of pulses per day which is significantly lower than our 
neighboring country India (3). It is grown in three seasons in a year in Bangladesh. Mungbean Yellow Mosaic virus (MYMV) is a major constraint in Bangladesh with $63 \%$ reduction in mungbean yield (4). That is why mungbean is not gaining popularity among the farmers of Bangladesh.

The virus infected leaves are characterized by a bright yellow mosaic appearance for mungbean yellow mosaic disease. The color, brightness, size of the yellow spot varied on the intensity of severity of the MYMV disease. The typical mosaic symptom is more visible in the early stage of disease development as whole leaf becomes yellow at the late stage of disease progression (5). The severity of the mungbean yellow mosaic disease is directly correlated with the time of infection and the abundance of insect vector- white fly (Bemisia tabaci) (6). The infectious agent is a virus species, Mungbean Yellow Mosaic Virus (MYMV) belongs to the ssDNA (single stranded DNA) viruses group, comprised in the family, Geminiviridae and placed in the genus, Begomovirus.

This disease incidence caused by the virus was first reported by by Nariani (7). During the last two decades, MYMV has emerged as a devastating plant disease causing agent, particularly in the tropics and subtropics. It is considered a prime limiting factor in mungbean production in Bangladesh causing a huge economic loss and threatening for mungbean production.

The use of resistant mutants in mungbean disease management is considered to be economical and safer as compared to the chemical control method. Bangladesh Institute of Nuclear Agriculture (BINA) have developed some advanced lines of summer mungbean which are high yielding and need to be evaluated against different biotic and abiotic stresses for their effectiveness as potential advanced lines. Therefore, these mutants need to be assessed for their resistance to disease against the existing summer mungbean varieties.

As per this requirement, the present research programme was undertaken to evaluate three mungbean mutants along with three released varieties, in terms of their resistance and yield attributing characters against MYMV.

\section{Materials and Methods}

Plant materials, experimental design and
intercultural operations

The experiment was done at the research field under the Department of Plant Pathology, Patuakhali Science and Technology University (PSTU), Dumki, Patuakhali-8602. The experiment was carried out during the summer period from February to April 2013. Highly sandy loam soil under the argo-ecological zone 13 (AEZ 13) belonging to the Ganges Tidal Flood Plain was used to conduct the experiment.

Seeds of three summer mungbean mutants MBM-07, MBM-21, MBM-88 and three released varieties Bina mung-5, Bina mung-6, Bina mung-8 were collected from BINA, Mymensingh, Bangladesh. To reduce the infection of seed borne diseases Provax-200 at $3 \mathrm{~g} / \mathrm{kg}$ seeds were used for seed treatment. The experiment was designed with Randomized Complete Block Design (RCBD) in three replications. The specific area of each plot was $3 \mathrm{~m} \times 3 \mathrm{~m}$. The distance between line to line 30 $\mathrm{cm}$, plant to plant $5 \mathrm{~cm}$, plot to plot $50 \mathrm{~cm}$, and replication to replication $1 \mathrm{~m}$.

The whole amount of urea, triple superphosphate (TSP), muriate of potash (MoP), boron, gypsum, and zinc sulfate were broadcast and incorporated into the soil during final land preparation at $40,80,37.5,60,2.0$ and $3.0 \mathrm{~kg} \mathrm{ha}^{-1}$, respectively along with cow dung at $10 \mathrm{t} \mathrm{ha}^{-1}$. Furrows were made for sowing of seeds with power tiller driven furrows maintaining a distance of $30 \mathrm{~cm}$. After completion of seed sowing, furrows were covered with soil. The seeds were sown in the morning on $10^{\text {th }}$ February 2013. To reduce the weed infestation along with reduction of diseases and pests, normal intercultural operations were performed to maintain good field condition for mungbean growth and development. Weeding was performed 20, 35 and 50 days after sowing of seeds. To control pod borer and thrips, insecticide 'Karate (0.2\%) and Dacis (0.2\%)' was applied respectively.

\section{Percent disease incidence (PDI)}

The plants in the experimental plots were allowed to occur natural infection. The affected plants were showing yellow specks along the veinlets and spreading over the lamina, the pods became thin and curled upward. In case of susceptible test entries, the whole leaves became yellow. The next trifoliate leaf emerging from the growing apex was showing irregular yellow and green patches alternating each other. The leaf size was not much affected. The plants showing such symptoms were rated as MYMV-infected plants.

$\begin{gathered}\text { Percent disease } \\ \text { incidence }\end{gathered}=\frac{\text { Number of plants infected in a plot }}{\text { Total number of plants in a plot }} \times 100$

The mutants and varieties were later grouped into different categories from immune to highly susceptible based on 0 to 9 scales (8). Furthermore, comparative yield performance along with the reproductive parameters were also studied among them.

\section{Data analysis}

Data were statistically analyzed using MSTAT-C software to find out significant differences among the treatments provided to this study. Mean for treatments were compared using Duncan's 
Multiple Range Test (DMRT) at 5\% level of significance.

\section{Results}

\section{Screening of mungbean mutants against Yellow Mosaic Virus Disease}

The percent disease incidence (PDI) was recorded at flowering and pod maturity stage during the study. The results were presented in Table 1 . PDI were more in pod maturity stage comparing with varied from $0.5 \%$ in MBM-21 to $26 \%$ in MBM-7 (Table 1 and 3). The PDI of Bina mung-8 recorded 3 $\%$ at the flowering stage but showed $13 \%$ at maturity stage. The mutants MBM-07 which recorded a disease incidence of $3 \%$ at flowering stage jump to $26 \%$ at maturity Stage and was considered as susceptible while MBM-21 was considered as the most resistant against MYMV at both flowering and maturity stage (Table 1).

Performance of six mungbean mutants and varieties in yield and yield contributing

Table 1. Screening of summer mungbean mutants and varieties against MYMV during February 2013 to April 2013

\begin{tabular}{cccccrr}
\hline SL.No. & $\begin{array}{c}\text { Mutants of } \\
\text { mungbean }\end{array}$ & $\begin{array}{c}\text { Total } \\
\text { plants }\end{array}$ & $\begin{array}{c}\text { Disease infected } \\
\text { plants at flowering } \\
\text { stage }\end{array}$ & $\begin{array}{c}\text { PDI (\%) at } \\
\text { flowering stage* }\end{array}$ & $\begin{array}{c}\text { Disease infected } \\
\text { plants at maturity } \\
\text { stage }\end{array}$ & $\begin{array}{c}\text { PDI (\%) at } \\
\text { maturity stage* }\end{array}$ \\
\hline 1 & MBM-07 & 200 & 6 & 3 & 52 & 26 \\
\hline 2 & MBM-21 & 200 & 1 & 0.5 & 1 & 6 \\
\hline 3 & MBM-88 & 200 & 2 & 2 & 1 & 3 \\
\hline 4 & Bina mung-5 & 200 & 4 & 0.5 & 2 & 5 \\
\hline 5 & Bina mung-6 & 200 & 1 & 3 & 26 & 1 \\
\hline 6 & Bina mung-8 & 200 & 6 & & & 13 \\
\hline
\end{tabular}

flowering stage for all the studied mutants and varieties except for MBM-21. The mungbean mutants and varieties were categorized into six different groups based on the disease incidence percent having a scale range 0-9 (Table 2 and 3).

During summer season, yellow mosaic incidence at flowering stage varied from $0.5 \%$ in MBM-21 and Bina mung- 6 to $3 \%$ percent in MBM-7 and Bina mung-8. The flowering stage of three genotypes i.e., MBM-21, MBM-88, Bina mung-6 were found resistant with a percent disease incidence of 0.5, 1.0 and 0.5 respectively (Table 1 and 2). The flowering stage of Bina mung-5, Bina mung-8 and MBM-7 were found moderately resistant showing 2,3 and 3 percent disease incidence. At maturity stage, no mutants showed immune against virus and the disease incidence

\section{characters}

There was a remarkable variation at days to $1^{\text {st }}$ flowering among different mungbean genotypes. Some mutants/varieties gave flower earlier while some took longer duration for $1^{\text {st }}$ flowering. It ranged from 33.00 days to 44.67 days. It has been observed that the highest $1^{\text {st }}$ flowering days was recorded in Bina mung-5 (44.67 days) and the lowest $1^{\text {st }}$ flowering days was recorded in Bina mung-8 (33 days) (Table 4).

The tested six mungbean mutants/varieties showed significant variation at days to $50 \%$ flowering. Some mutants/varieties were gave $50 \%$ flower in earlier duration and some took longer duration to $50 \%$ flowering. It ranged from 38.33 days to 50 days. It has been observed that the

Table 2. Grouping of mutants screened against MYMV during summer at flowering Stage

\begin{tabular}{clll}
\hline Scale & Description & Categories & Mutants \\
\hline 0 & No. plants showing any symptoms & Immune & Nil \\
\hline 1 & $1 \%$ or less plants exhibiting symptoms & Resistant & MBM-21, MBM-88, Bina mung-6 \\
\hline 3 & $1-10 \%$ plants exhibiting symptoms & Moderately resistant & MBM-07, Bina mung-5, Bina mung-8 \\
\hline 5 & $11-20 \%$ plants exhibiting symptoms & Moderately susceptible & Nil \\
\hline 7 & $21-50 \%$ plants exhibiting symptoms & Susceptible & Nil \\
\hline 9 & $51 \%$ plants exhibiting symptoms & Highly susceptible & Nil \\
\hline
\end{tabular}

Table 3. Grouping of mutants screened against MYMV during summer at maturity stage

\begin{tabular}{clll}
\hline Scale & Description & Category & Mutants \\
\hline 0 & No. plants showing any symptoms & Highly Immune & Nil \\
\hline 1 & $1 \%$ or less plants exhibiting symptoms & Resistant & MBM-21, Bina mung-6 \\
\hline 3 & $1-10 \%$ plants exhibiting symptoms & Moderately resistant & MBM-88, Bina mung-5 \\
\hline 5 & $11-20 \%$ plants exhibiting symptoms & Moderately susceptible & Bina mung-8 \\
\hline 7 & $21-50 \%$ plants exhibiting symptoms & susceptible & MBM-07 \\
\hline 9 & $51 \%$ plants exhibiting symptoms & Highly susceptible & Nil \\
\hline
\end{tabular}


highest and lowest $50 \%$ flowering days was recorded in Bina mung-5 (50 days) and MBM-88 (38.33 days) respectively (Table 4). The remaining four genotypes remained in the intermediate position for days to $50 \%$ flowering.

In case of days to maturity, distinctive differences were pointed out among the mungbean mutants/varieties. Some mutants/varieties matured earlier and some took
Pod length ranged from 6.767 to 9.40 where the lowest pod length was recorded in MBM-07 (6.767 $\mathrm{cm})$ and the highest pod length was recorded in MBM-21 (9.40 cm) (Table 5).

Marked variation was noticed in respect of seed number per pod. The number of seeds per pod was recorded after harvesting by counting seed in a pod from ten plants in every genotype. Number of seeds per pod ranged from 8.867 to

Table 4. Days to $1^{\text {st }}$ flowering, days to $50 \%$ flowering and days to maturity of mungbean mutants and varieties under field condition during summer, 2013

\begin{tabular}{|c|c|c|c|c|c|c|c|}
\hline Name of mutants & Days to $1^{\text {st }}$ flowering & $\begin{array}{l}\text { Days to } \\
\text { flower }\end{array}$ & ing & $\begin{array}{l}\text { Days to } \\
\text { maturity }\end{array}$ & Plant height & $\begin{array}{c}\text { No. of } \\
\text { branch/plant }\end{array}$ & No. of Pod/plant \\
\hline MBM-07 & $37.33 \mathrm{bc}^{*}$ & 43.33 & $\mathrm{~b}$ & $64.00 \mathrm{ab}$ & $35.60 \mathrm{a}$ & $4.200 \quad \mathrm{a}$ & $16.13 \mathrm{a}$ \\
\hline MBM-21 & $33.67 \mathrm{~b}$ & 39.33 & $\mathrm{c}$ & $61.67 \mathrm{~b}$ & $37.53 \mathrm{a}$ & $3.533 \mathrm{ab}$ & $23.67 \mathrm{a}$ \\
\hline MBM-88 & $33.67 \mathrm{~d}$ & 38.33 & $\mathrm{c}$ & $60.33 \mathrm{~b}$ & $34.87 \mathrm{a}$ & $3.400 \mathrm{ab}$ & $19.13 \mathrm{a}$ \\
\hline Bina mung-5 & $44.67 \quad \mathrm{a}$ & 50.00 & $\mathrm{a}$ & $66.67 \mathrm{a}$ & $34.47 \mathrm{a}$ & $2.733 \quad \mathrm{ab}$ & $14.13 \mathrm{a}$ \\
\hline Bina mung-6 & $37.67 \mathrm{~cd}$ & 44.00 & $\mathrm{c}$ & $67.33 \mathrm{a}$ & $39.27 \mathrm{a}$ & $4.467 \quad \mathrm{a}$ & $23.40 \mathrm{a}$ \\
\hline Bina mung-8 & $33.00 \mathrm{~d}$ & 39.00 & c & $62.67 \mathrm{~b}$ & $36.47 \mathrm{a}$ & $3.933 \mathrm{ab}$ & $21.27 \mathrm{a}$ \\
\hline $\mathrm{LSD}^{* *}$ & 3.63 & 2.85 & & 3.85 & 10.34 & 1.187 & 12.25 \\
\hline $\mathrm{CV}^{* * *}$ & 5.45 & 3.71 & & 3.33 & 15.63 & 17.59 & 34.31 \\
\hline
\end{tabular}

*Values in columns followed by the same letter are not significantly different, LSD ${ }^{* *}$ LSD: Least Significant Difference; $* * * \mathrm{CV}$ : Coefficient of Variation

longer duration to mature. Maturity period ranged from 61.67 days to 67.33 days among the studied materials (Table 4). In this study, long duration mutant was recorded in Bina mung-6 (67.33 days) while short duration was recorded in MBM-21 (61.67 days) (Table 4).

Among the tested six mutants/varieties plant height was statistically identical to each other in the field condition (Table 4). The plant height ranged from 34.47 to $39.27 \mathrm{~cm}$ while the tallest plant was recorded in Bina mung-6 (39.27 $\mathrm{cm})$. The shortest plant was recorded in Binamung-5 $(34.47 \mathrm{~cm})$ (Table 4$)$.

There were significant variations among the mungbean mutants/varieties for branch per plant. It was counted as the primary branch of plant that is the first branching of the plant and significantly differs from one to others. It was found that number of branch per plant ranged from 2.733 to 4 . 467. The maximum number of branch per plant was found in Bina mung-6 followed by MBM-07 (4.20). The minimum number of branch per plant was counted in Bina mung-5 followed by MBM-88 (3.40) (Table 4).

Number of pod per plant was recorded after harvesting. Pods were counted from ten plants in every genotype and showed significantly different from one to others (Table 4). Number of pod per plant ranged from 14.13 to 23.67, while the minimum number of pod was recorded in Bina mung-5 (14.13) and maximum number of pod per plant was observed in MBM-21 (23.67) (Table 4).

To avoid shrinkage, pod length was taken immediately after harvesting of previously selected 10 plants from each genotype (Table 5).
10.93 where lowest number of seeds per pod was recorded in MBM-88 (8.867). The highest number of seed per pod was recorded in MBM-21 (10.93) (Table 5).

Mungbean grain (seed) yield per hectare differs significantly from one to another genotypes under field condition (Table 5). The yield ranged from $1183 \mathrm{~kg} \mathrm{ha}^{-1}$ to $1569 \mathrm{~kg} \mathrm{ha}^{-1}$ where highest yield was recorded in MBM-21 (1569 $\mathrm{kg} \mathrm{ha}^{-1}$ ) and lowest in MBM-07 (1183 kg ha-1) (Table 5).

\section{Discussion}

Host resistance regarded as rock-bottom avenue of disease management with maintaining a tenuous environmental perturb. Justifying the existing mungbean mutants and varieties under field condition in an uncontrolled environment is the first step to identify the resistant genotypes against MYMV.

Findings of the experiment debunked that, all the three mungbean mutants and three released mungbean varieties were sentient to MYMV in a varied level. The response of tested mutants and varieties to MYMV mostly dovetailed with growth stages. The maturity stage was comparatively more prone to MYMV than the flowering stage. But some mutants were vulnerable at the flowering stage also. These findings corroborate with the findings of Singh and Awasthi (9); Gill (10).

The results of present screening were in accordance with several other findings. In a cross breeding programme, Khattak (11) found significant differences for MYMV disease infection 
among the 14 MYMV susceptible $\mathrm{F}_{3}$ progenies. Iqbal (12) found 4, 8, 30, 30, 28 mungbean genotypes as resistant, moderately resistant, moderately susceptible, susceptible and highly mungbean yellow mosaic virus infection affects grain yield and reduction in yield contributing characters such as pods/plants, seeds/pods, 100 seed weight. Khattak (11) also found significant

Table 5. Length of pod and number of seeds/pod of mungbean mutants and varieties under field condition during summer 2013

\begin{tabular}{lccc}
\hline \multicolumn{1}{c}{ Name of the mutants } & Length of pod $(\mathrm{cm})$ & No. of seeds / pod & Yield $\left(\mathrm{kg} \mathrm{ha}^{-1}\right)$ \\
\hline MBM-07 & $6.767 \mathrm{~b}^{* * *}$ & $9.867 \mathrm{ab}$ & $1183 \mathrm{~b}$ \\
\hline MBM-21 & $9.400 \mathrm{a}$ & $10.93 \mathrm{a}$ & $1569 \mathrm{a}$ \\
\hline MBM-88 & $7.033 \mathrm{~b}$ & $8.867 \mathrm{~b}$ & $1388 \mathrm{ab}$ \\
\hline Bina mung-5 & $7.967 \mathrm{~b}$ & $10.07 \mathrm{ab}$ & $1397 \mathrm{ab}$ \\
\hline Bina mung-6 & $7.917 \mathrm{~b}$ & $9.000 \mathrm{ab}$ & $1427 \mathrm{ab}$ \\
\hline Bina mung-8 & $7.633 \mathrm{~b}$ & $10.00 \mathrm{ab}$ & $1418 \mathrm{ab}$ \\
\hline LSD* & 1.352 & 1.812 & 320.1 \\
\hline CV $^{* *}$ & 9.54 & 10.17 & 12.34
\end{tabular}

*LSD: Least Significant Difference; ${ }^{* *}$ CV: Coefficient of Variation; ${ }^{* * *}$ : Values in columns followed by the same letter are not significantly different, LSD.

susceptible to MYMV respectively. Karim (13) found only 10 genotypes as resistant among 60 mungbean advanced lines against MYMV. Paul et al. (14) screened eighteen mungbean germplasm against MYMV and found one resistant genotype (ML-818), one was susceptible (Pusa baisaki). Remaining nine and seven genotypes were moderately resistant and moderately susceptible respectively. PANT-M-4, ML-818, IPM-99-125, Pusa2072, UPM-9903, SML-668, PDM-139, Asha, PS-16 and MH-96-1 were found prominent lines against mosaic infection. Shakoor et al. (15) screened eight mutants among where six mutants namely Pak 3, Pak 13, Pak 18, Pak 22, Pak 32 and 6601 exhibited resistance to MYMV.

Mungbean mutants and varieties exhibited a conspicuous contrast in case of Days to $1^{\text {st }}$ flowering, $50 \%$ flowering and maturity. The relative early or lateness of flowering might be owing to the genetic potential of those mutants/varieties rather than the MYMV infestation. It is similar with the findings of Anon (16).

The tested six mungbean mutants and varieties showed a difference in their plant height, branch per plant, Number of pods per plant. The plant height, pod length was statistically identical whereas the branch per plant showed significantly different. It was supposed that, the genetic makeup of the mutants and varieties might result such variation. This is coinciding with the results of previous studies (16-19).

The findings of the experiment revealed that, MYMV effectuate the yield contributing characters of Mungbean i.e length of pod, seeds/pod etc. Leaf, the photosynthetic venue is exceedingly oppressed by the infection of MYMV which ultimately abate the photosynthetic rate. We assumed that, the lower photosynthetic rate may hamper the yield and yield contributing traits of mungbean mutants and varieties. Vohra and Beniwal (20) and Babu et al. (21) reported that differences for MYMV in terms of disease infection, yield and yield components.

We hypothesized that, test entries appeared to be as resistant, might be owing to their genetic competence to grapple against MYMV. The increased disease incidence also might be due to prevalence of conducive environment for disease development.

However, the foremost grail of classifying the mutants is to carry out a fundamental and applied research so as to dissect its genetic diversity. The mutants grouped under resistant category would be utilized as donors to develop MYMV resistant lines. For additional corroboration, these mutants will be screened through artificial screening methods like forced feeding method, agro-inoculation method etc., to confirm resistance against MYMV.

\section{Conclusion}

It was observed that the evaluated mungbean mutants/varieties differed significantly in respect of the response to MYMV infection, days to $1^{\text {st }}$ flowering, 50\% flowering, maturity, plant height, number of branch per plant, number of pod per plant, pod length, number of seeds/pod, and yield. Finally, it may be concluded that out of six mutants and varieties only one mutant viz. MBM21 was found resistant to MYMV and high yielding. So, this mutant should be confirmed as a resistant genotype through artificial inoculation before using it in a breeding programme for recommending as MYMV resistant and high yielding variety.

\section{Acknowledgements}

The authors are thankful to the Head, Department of Plant Pathology, Patuakhali Science and Technology University, Dumki, Patuakhali-8602, 
Bangladesh for providing all the facilities including research field.

\section{Funding}

This research received no external funding.

\section{Conflicts of Interest}

The authors declare no conflict of interest.

\section{Author Contributions}

Conceptualization and writing-original draft preparation: Md. Mahmudul Hasan Arif Sardar, Habibur Rahman; Writing-review and editing: Mohammad Saiful Alam Sarker, Kazi Khayrul Bashar; Supervision: Habibur Rahman, Md. Shahidul Islam.

\section{References}

1. BBS. 2004. Statistical Yearbook of Bangladesh. Bangladesh Bureau of Statistics (BBS). Statistics Division. Ministry of Planning. Govt. of the People's Republic of Bangladesh) Dhaka. $14 \mathrm{p}$.

2. Khan MRI, Shaikh MAC, Dutta PC. Nutritional quality characters in pulses. Field Crop Abst. 1995; 48(1):37.

3. FAO (Food and Agriculture Organization). FAO Production year book, Basic Data Unit, Statistics Division, FAO, Rome, Italy. 2002; 51:125-127.

4. Bakr, MA. Check list of pulses disease in Bangladesh. Bangladesh J. Plant Pathology. 1994; 10(1\&2):13-16.

5. Singh BR, Singh M, Yadav MD, Dingar SM. Yield loss in mungbean due to yellow mosaic. Science and Culture 1982; 48(12): 435-436.

6. Dhingra KL, Ghosh DK. Efficiency of white fly vector (Bemisia tabaci) in transmission of mungbean yellow mosaic virus in different source test plant combination. Int J Trop Agric. 1993; 11(2): 149-152.

7. Nariani TK. Yellow Mosaic of Mungbean (Phaseolus aureus). Indian Phytopathol. 1960; 13: 24-29.

8. Jayappa, Ramappa HK, Sab J, Gautam C and Devamani BD. Screening of mungbean genotypes against mungbean yellow mosaic virus disease. Int J Curr Microbiol App Sci. 2017; 6(5):1746-1752. https://doi.org/10.20546/ijcmas.2017.605.189

9. Singh S, Awasthi LP. Varietal screening of yard bean against mungbean yellow mosaic virus under field conditions. Ann Plant Protect Sci. 2004; 12(1): 225226.

10. Gill CK. Effect of mungbean yellow mosaic virus on yield components in mungbean cultivar. Insect Environment 1999; 5(3): 112-113.

11. Khattak GSS, Haq MA, Rana SA, Abbas G, Irfan M. Effect of Mungbean Yellow Mosaic Virus (MYMV) on Yield and Yield Components of Mungbean (Vigna radiata (L.) Wilczek). Kasetsart J Nat Sci. 2000; 34: 12-16.

12. Iqbal U, Sheikh MI, Rukhsana A, Atif J, Muhammad AF, Ashraf Z. Screening of mungbean germplasm against mungbean yellow mosaic virus (MYMV) Under Field Conditions. Pak J Phytopathology. 2011; 23(1): 48-51.

13. Karim Z, Bakr MA, Hossain MS, Islam MM. Searching MYMV resistant mungbean genotype: A field screening. New perspectives of pulse research in Bangladesh 2007. p. 75-78.

14. Paul CP, Biswas MK, Mandal D, Pal P. Studies on host resistance of mungbean against Mungbean yellow mosaic virus in the agro-ecological condition of lateritic zone of West Bengal. Bioscan 2013; 8(2): 583-587.

15. Shakoor A, Haq MA, Sadiq MS, Sarwar M. 1977. Induction of resistance to yellow mosaic virus in mungbean through induced mutation. Plant Dis. 214: 293-302.

16. Anon. 2009. Annual report Pulses Research Centre. BARI, Joydebpur, Gazipur.

17. Venkateswarlu MS, Rajan, MSS. Influence of season on growth and yield attributes of black gram (Phaseolus mungo). Indian J. Agro. 1991; 36 (supplu.): 119-123.

18. Akter MS. 2011. Effect of Dates of Sowing on Incidence and Severity of Diseases of Mungbean. M.S. Thesis Submitted to the Department of Plant Pathology, BAU, Mymensingh. 65 p.

19. Dharmalingam C, Basu RN. Determining optimum season for the production of quality seeds in mungbean. Madras Agril. J. 1993; 80(12): 684-688.

20. Vohra K, Beniwal SPS. Effect of mungbean yellow mosaic virus on yield and seed quality of mungbean (Vigna mungo L). Seeds Research. 1979; 7(2):168-174.

21. Babu RC, Rathinaswamy R, Srivasan PS, Natarajaratnam N, Sreerangssamy SR. Certain physiological changes in green gram plants infected by mungbean mosaic virus. Madras Agric J. 1984; 71(12): 795-798. 